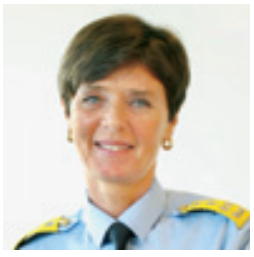

\title{
Politi og helse - til beste for alle
}

\section{Det må være et mål både for helseve- senet og for politiet å få frem det gode samarbeidet som hver dag finner sted over hele landet. Det er viktig at vi selv tar ansvar for å formidle de positive aspektene.}

Det er viktig å understreke det gode samarbeidet for å gi motivasjon og ros til våre ansatte. Dessuten er det et poeng at politikere og bevilgende myndigheter får den riktige informasjonen om hvor mye som fungerer bra, og hvor viktig det er at det settes av ressurser til at dette får fortsette.

Og vi må ta dette ansvaret selv. Det moderne mediesamfunnet er opptatt av dramaturgi, konflikt og det som ikke fungerer. Nå er det pressens rolle å avdekke feil og mangler, det som ikke går etter planen eller hvor det gikk galt. Men da blir det desto viktigere at politi og helsevesen selv tar ansvar for å få formidlet de mange gode resultatene av vårt samarbeid, slik at det offentlige ordskiftet bygger på riktige forutsetninger.

\section{Krevende oppdrag}

Vi har samarbeidsflater som i sin natur er mer besværlige enn andre. En av disse er ivaretakelsen av psykisk syke mennesker. Ofte er det slike saker som frustrerer internt, og som får oppslag i mediene. Vi ser og leser reportasjer om fortvilte politi- tjenestemenn som kjører rundt med en ustabil og opplagt psykisk syk person, $i$ håp om at vedkommende kan tas vare på av kvalifisert helsepersonell. Helsearbeidere fortviler over at psykisk syke mennesker må sitte «på cella», riktignok under tilsyn.

I enkelte dramatiske saker kommer også spørsmålet opp om taushetsplikt, samarbeidsrutiner og ansvarsplassering. I slike situasjoner er det naturlig at ulike profesjoner har ulikt utgangspunkt, og at man vegrer seg for å ta på seg et ansvar man mener man ikke har, i hvert fall ikke alene. Da er det betryggende at vi i hvert fall har tatt noen steg i riktig retning de siste årene. Vi håper at rundskrivet som Politidirektoratet og Sosial- og helsedirektoratet utga i 2006, medvirker til økt forståelse av ansvarsforhold og behov for samarbeid.

Politiets utgangspunkt er at vi skal være en bistands- og støtteenhet for helsevesenet. Vi skal fremfor alt ivareta liv og helse, og dersom taushetsplikten er til hinder for dette, så ivaretas ikke det viktigste hensynet. Derfor slår forordet i det felles rundskrivet fast at hensynet til å avverge en alvorlig skade på person eller eiendom går foran den enkeltes krav på konfidensialitet $i$ helsetjenesten. Helsepersonells taushetsplikt vil derfor ikke være til hinder for at politiet varsles for å sikre nødvendig oppfølging i disse situasjonene. På samme tid understreker rundskrivet politiets ansvar for å varsle helsetjenesten ved behov, og for å yte nødvendig bistand.

\section{Kompetanse og ressurser}

Med bakgrunn i mye godt opparbeidet samarbeid, og som nevnt en vilje til å utvikle felles rammer for god håndtering, kan vi ha tro på at vi over tid vil få en enda bedre flyt av den nødvendige informasjon mellom våre to profesjoner, og derved også en bedret stilling for mennesker i vanskelige situasjoner. Utfordringene med den konkrete vurdering fra sak til sak må ikke forhindre at vi utvikler oss i den samme retningen.

Forutsetningen er at vi både kompetansemessig og ressursmessig settes i stand til å ivareta også de tidkrevende og vanskelige sakene, hvor det må utvises en stor grad av menneskelige hensyn. Her har vi en felles jobb å gjøre.

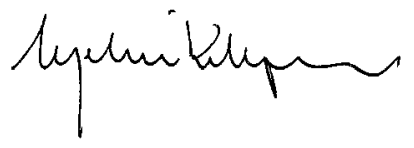

\section{I neste nummer:}

\author{
Sanatoriebarn \\ Ryggsmerter \\ Utstyr ved kommunale \\ legevakter
}

Arbeidsskadedødsfall

Follikulær okklusjonssykdom

Behandling av akutt hoste 